\title{
O kilku innowacyjnych sposobach językowego ujęcia relacji homo-animal w mowie współczesnych miłośników zwierząt
}

Prace naukowe dotyczące wizerunku istot żywych utrwalonego w języku polskim ${ }^{1}$ wskazują zazwyczaj na trzy cechy konstytutywne dla tego obrazu i ściśle z sobą wzajemnie powiązane. Pierwszą z nich jest ujmowanie zjawisk natury z perspektywy człowieka, tj. ze względu na jego fizyczność (wymiary ciała, pionową postawę itp.), zdolności percepcyjne i poznawcze (np. dominacja zmysłu wzroku czy relatywna słabość węchu), potrzeby (korzystanie z żywności zwierzęcego pochodzenia, wykorzystywanie niektórych gatunków jako siły roboczej) oraz pragnienia (m.in. marzenia o lataniu, uwidocznione w konotacjach ptaka i niektórych jego hiponimów (Kępa-Figura 2007)). Drugą cechą sposobu myślenia o przyrodzie odzwierciedlonego w polszczyźnie jest hierarchizowanie i wartościowanie organizmów zgodnie z kulturowym modelem wielkiego łańcucha bytów, przyznającym najwyższy status człowiekowi (Libura 2001; Tokarski 2013, s. 145-147). Trzecia własność to rozgraniczanie tego, co ludzkie, i tego, co dotyczy pozostałych istot żywych. Wyrazistym językowym przejawem dążenia do dyferencjacji obu tych dziedzin jest zasadniczo negatywny obraz ssaków, nazywanych potocznie zwierzętami. Ich charakterystyka aksjologiczna w polszczyźnie stanowi konsekwencję tego, że są one do ludzi najbardziej podobne pod względem anatomii i fizjologii, co rodzi silne pragnienie odróżnienia się.

Wspomniane tu własności obrazu językowego są dobrze opisane w polskiej literaturze lingwistycznej, niemniej jednak badania pokazały również, że członko-

${ }^{1}$ Kwestia ta cieszyła się w lingwistyce sporym zainteresowaniem. (zob. np. Kempf 1985; Pajdzińska 1990; Mosiołek-Kłosińska 1998; Zaron 1998; Skawiński 2001; Tokarski 2001, 2002; Dąbrowska 2003; Grybosiowa 2003; Kamińska-Szmaj 2003; Nowakowska 2003; Peisert 2003; Wolny 2003; Wysocka 2003, 2011; Wysoczański 2003; Zimnowoda 2003; Wierzbicka 2006). 
wie naszej wspólnoty komunikacyjnej, tworząc werbalne, a zatem i konceptualne ujęcia przyrody ożywionej, nie zawsze kierowali się skłonnością do absolutyzowania ludzkiej perspektywy, wytyczania ostrych granic kategorii gatunkowej MY i dowartościowywania jej reprezentantów poprzez deprecjację tego, co znajduje się poza linią demarkacyjną (Termińska 2003; Krawczyk-Tyrpa 2003)². Analizy językoznawcze dowiodły również, że naszkicowane tu mechanizmy, których działanie wywarło przemożny wpływ na kształt współczesnego obrazu językowego, są zrelatywizowane historycznie. W tekstach piętnasto- i szesnastowiecznych ,nie ma $[\ldots]$ jeszcze podziału na słownictwo związane z człowiekiem i ze światem istot żywych, które człowiek sobie podporządkował" (Grybosiowa 2003, s. 13), opozycja homo-animal staje się wyrazista dopiero w epoce oświecenia, co w polszczyźnie przejawiło się wyodrębnieniem rodzaju męskoosobowego i przesunięciami leksykalnymi (Grybosiowa 2003, s. 14) ${ }^{3}$. Z kolei w diagnozach współczesnej rzeczywistości społecznej formułowana jest hipoteza o „zmierzchu antropocentrycznego paradygmatu" 4 i wejściu w kolejne stadium kulturowej ewolucji, cechujące się wzrostem krytycyzmu wobec konwencjonalnych modeli kategoryzacji i wartościowania istot żywych. Czy owa tendencja, sygnalizowana przez naukowców i nagłośniona przez publicystów ${ }^{5}$, odzwierciedliła się w językowym kształcie współczesnych wypowiedzi na temat relacji człowiek-zwierzę? Odpowiedź na to pytanie byłaby najpewniej różna, w zależności od tego, jakich nadawców i jakie gatunki tekstu poddalibyśmy analizie. W swoich badaniach skupiłam się na jednej tylko społeczności, a mianowicie na miłośnikach zwierząt, którzy $\mathrm{w}$ internecie, na licznych i różnorodnych stronach o charakterze hobbystycznym, piszą o swoich domowych ulubieńcach ${ }^{6}$, a także o zwierzętach, z którymi mają kontakt $\mathrm{w}$ schroniskach oraz $\mathrm{w}$ innych instytucjach opiekuńczych. Witryny stanowiące dla mnie źródło materiału językowego zawierały porady, głosy w dyskusji

2 Także analiza użycia zaimków (kto, ktoś, co, coś) w kontekście podmiotowości bytów rodzi nowe pytania o językowy status zwierząt (Zaron 1998).

3 Polska literatura, dawna i współczesna, czerpiąca przecież z obserwacji życia codziennego, również przynosi obrazy bliskich i serdecznych więzi ludzi ze zwierzętami, że wspomnę tylko o bohaterach utworów szczególnie ważnych dla naszej tradycji — o wydrze Robaku z Pamiętników Jana Chryzostoma Paska czy o psie Sabie i słoniu Kingu z powieści Henryka Sienkiewicza $W$ pustyni i w puszczy.

4 To sformułowanie zostało użyte w haśle konferencji Zwierzęta i ich ludzie. Zmierzch antropocentrycznego paradygmatu, zorganizowanej przez Instytut Badań Literackich PAN, która odbyła się w marcu 2014 roku w Warszawie.

5 Jako przykład weźmy „Pomocnik Psychologiczny” (dodatek do „Polityki”) z 13 grudnia 2008 roku, pod wymownym tytułem Między nami (a) zwierzętami. Warto także zwrócić uwagę na nową rubrykę kwartalnika literackiego „Akcent”, nazwaną „W zwierciadle gatunku”, w której ukazują się artykuły naukowe i eseje dotyczące różnych aspektów kulturowej interpretacji świata istot żywych.

${ }^{6}$ W polszczyźnie nie ma jednowyrazowej nazwy na określenie kategorii zwierząt trzymanych w domach dla przyjemności (klasa, do której odsyła wyrażenie zwierzę domowe, jest szersza), inaczej niż np. w języku angielskim, w którym funkcjonuje wyraz pet. (Dziękuję recenzentowi za tę uwagę). 
na forach, a także ogłoszenia. Komunikaty były zatem zróżnicowane gatunkowo, a także pod względem poziomu spontaniczności i staranności. Przytaczając je, zachowuję oryginalną formę zapisu.

\section{Sposoby nazywania podmiotów relacji człowiek-zwierzę}

Tradycyjnymi określeniami człowieka w relacji do zwierzęcia domowego są rzeczowniki pan (pani) i właściciel (właścicielka). Słownik współczesnej polszczyzny ogólnej pod hasłem pan podaje: Jeśli zwierzę domowe, np. pies, ma swojego pana, to ma wtaściciela, który się nim opiekuje (Bańko (red.) 2000). Interesujące mnie znaczenie obu tych wyrazów leksykografowie ilustrują następującymi użyciami:

Wlaściciel psa powinien zaszczepić go przeciw wściekliźnie. Psiak chodził wszędzie za swoim panem... Azor, chodź do pana! (Bańko (red.) 2000).

Dobór przykładów sugeruje, że nazwa właściciel, zastosowana tu w wypowiedzi deontycznej, jest charakterystyczna dla stylu urzędowego, natomiast słowo pan - dla potocznej odmiany języka, reprezentowanej przez drugie i trzecie zdanie. Rzeczywiście, w aktach prawnych dotyczących interesującej mnie relacji, do których dotarłam, użyto kategorii właściciela, także w najważniejszym spośród nich, tj. w Ustawie z dnia 21 sierpnia 1997 r. o ochronie zwierząt (Dz.U. $1997 \mathrm{Nr}$ 111, poz. 724 ), przyznającej im podmiotowy status 7 . Z kolei we frazeologii potocznej utrwaliły się dwa połączenia właśnie ze słowem pan: nieregularne semantycznie wyrażenie pański piesek 'osoba bardzo wybredna, zwłaszcza w kwestiach kulinarnych' oraz zestawienie bezpański pies 'taki, który nie należy do żadnego człowieka, nie ma opiekuna'.

Słowniki rejestrują także potoczną formę pańcia, co ciekawe, tylko żeńską (Bańko (red.) 2000). Ów żartobliwy derywat od pani zawiera komponent semantyczny 'traktowania zwierzęcia z czułością', nie konotuje natomiast — inaczej niż pan/pani - 'przewagi człowieka nad podległym mu stworzeniem'. Wydaje się zatem, że przyczyny utworzenia i spopularyzowania hipokorystyku są dwie: potrzeba ekspresji pozytywnych, ciepłych uczuć oraz chęć zdystansowania się od konceptualnego modelu WŁADZY, który stanowił podstawę określeń standardowych. Natomiast brak męskiego odpowiednika pańci w słownikach polszczyzny ogólnej wydaje się sygnałem obecnego w językowej interpretacji świata, stereotypowego wyobrażenia o uwarunkowanej płcią różnicy w sposobie traktowania zwierząt. Sąd o tym, że dziewczęta i kobiety mają skłonność do uczuciowości

${ }^{7}$ Ustawa ta rozpoczyna się słowami: „Zwierzę, jako istota żyjąca, zdolna do odczuwania cierpienia, nie jest rzeczą". Szerzej o tym (Zaron 1998). 
wobec żywych stworzeń, jest implikowany również przez potoczne wyrażenia kocia mama i psia mama, odnoszone zwykle do dziewczynek, przejawiających szczególne (zdaniem niektórych — nadmierne) upodobanie do czułej opieki nad psem bądź kotem. O kocim czy psim tacie się nie słyszy.

$\mathrm{W}$ wypowiedziach internautów dość często padały określenia pan i właściciel, co, rzecz jasna, nie oznacza, że ich autorzy chcieli uwypuklić aspekt władzy nad zwierzęciem czy też ekonomiczny bądź prawny wymiar jego relacji z człowiekiem. W większości użyć motywacja semantyczna wydaje się sprawą drugorzędną, gdyż obie konwencjonalne nazwy pojawiają się w bardzo różnych kontekstach, zarówno pozytywnych, jak i negatywnych ${ }^{8}$. W badanym materiale szczególnie częste były natomiast spieszczenia, nie tylko żeńskie — pańcia - rejestrowane przez słowniki, lecz także innowacyjne: pańcio, pańciostwo, pańciowie 'pan i pani', zapisywane małą lub wielką literą.

Jutro spacerek dogtrekkingowy po lasach i po gorach w towarzystwie znajomej beagelki i jej panci, ktora planuje dac nam lekki wycisk (www.facebook. com/wychowujenietresuje).

Pańcia nie męcz mnie !!! Jestem po jedzeniu (http://www.youtube.com/ watch?v=NmTJGirnysc; tytuł filmu, którego bohaterem jest kot).

Oczywiście mieszka w domu, a cały dzień drepcze po swoich hektarach, pilnując, doglądając inwentarza i towarzysząc pańciowi w codziennych pracach. Nie mieszka w żadnym kojcu, bo zamknięty i odizolowany od świata akita traci całą swoją osobowość i może stać się niebezpieczny... (zurawiejka-huculy.gogler.pl).

Re: czy są tu Pańcie/Pańciowie ;) kotów bengalski(ch) (forum.gazeta. pl〉Forum〉Zwierzęta).

...pańciostwo [...] nieco ogłuchli od wściekłego ryku ulubieńca oraz stracili nieco skóry z dłoni podczas przytrzymywania w/w na skórzanej smyczy bez solidnych rękawic ochronnych (zurawiejka-huculy.gogler.pl).

${ }^{8}$ Oto kilka przykładów: Zaginęła ta oto sunia w typie jamnika. Bez ogonka! Wtaściciele siwieja ze zmartwienia pod numerem... (www.facebook.com/FoondacjaFelis). To właśnie tego dnia ówczesny wlaściciel psa porzucił go na terenie schroniska z informacja, że pies pogryzł (przygarnijzwierzaka). Freddie jest pięknie umaszczonym psem, przed którym dtugie życie - oby szcześliwe u nowego wtaściciela, którym możesz zostać TY (przygarnijzwierzaka). Porady dla właścicieli kotów wychodzacych (www.koty.pl) ...trudno opiekować się psem, który nie odstępuje wtaściciela nawet na chwile (www.psy.pl). ...mieliśmy nadzieję, że jego pan rozpaczliwie go szuka $i$ w końcu odnajdzie... I niestety, pomyliliśmy się (przygarnijzwierzaka). Spacer jest po to, by psa zmęczyć-żeby pan miat potem święty spokój (www.psy.pl). Pewna rozkochana w labradorach osoba powiedziała kiedyś bardzo mądre zdanie: „Każdy pies jest mądry mądrościa swego pana” (www.fundacjaprima.pl). 
Było cudnie! Uchodowałam (tak!) sobie sopelki na paszczy :)) iiii bałwany między paluszkami łapek — ale Pańciowie mi je pomogli wydłubać (ponforum.x25. $\mathrm{pl}^{9}$ ).

Innym popularnym określeniem człowieka w relacji do zwierzęcia, rozpowszechnionym zwłaszcza w ogłoszeniach o charakterze perswazyjnym, jest opiekun. Czasem ze względów stylistycznych wyraz ten bywa stosowany wymiennie np. z właścicielem (patrz przykład zacytowany jako pierwszy), lecz częściej jego użycie wydaje się rezultatem świadomego wyboru leksykalnego (co pokazują przykłady zacytowane w drugiej kolejności).

Jeden z najczęstszych problemów, jaki mają właściciele ze swoimi psami. Ciągnięcie na smyczy sprawia, że spacery zamieniają się w koszmar, a opiekunowie często nie wiedzą, jak sobie z tym poradzić (www.psy.pl).

12-letni pięknie umaszczony kocurek, kastrat, osierocony przez opiekunkę... (fundacjafelis.org).

7 letni skrzywdzony psiak szuka opiekuna odpowiedzialnego i opiekuńczego (przygarnijzwierzaka).

Ma typowo terierowaty charakter — nie da sobie w kaszę dmuchać ;), dlatego wymaga konsekwentnego opiekuna, który jasno będzie wyznaczał jej granice (www.morusek.pl).

Kubuś jest kilkuletnim, lubiącym pogadać z człowiekiem kotem. Z powodu choroby swojej dotychczasowej opiekunki stracił dom i trafił do stada bezdomnych kotów mieszkających na jednym z warszawskich cmentarzy... (www.morusek.pl).

Redundantne sformułowanie szuka opiekuna odpowiedzialnego i opiekuńczego w ekspresywny sposób wyraża oczekiwania wobec ludzi, projektuje mianowicie model relacji, w którym najważniejsza jest troska o zwierzęta. Warto też zwrócić uwagę na odniesione do człowieka przymiotniki odpowiedzialny i konsekwentny, sugerujące, że podopieczni mogą sprawiać kłopoty.

$\mathrm{W}$ wypowiedziach internautów popularny jest również wyraz przyjaciel, zarówno na oznaczenie zwierzęcia w relacji do człowieka (przykład pierwszy), jak i na odwrót (przykład drugi).

Jednym słowem - kot zmienia nas każdego dnia. Wspaniale wraca się z pracy do domu wiedząc, że właśnie taki przyjaciel czeka (www.koty.pl).

Doskonale wyczuwa nastroje opiekuna, potrafi przytulać się kiedy człowiekowi jest naprawdę źle, pocieszać, jest wyjątkowym przyjacielem (www. morusek.pl).

9 PON to skrót od polski owczarek nizinny. Cytat dotyczy zabaw długowłosego psa tej rasy na śniegu. 
MOREL — jeśli szukasz przyjaciela (przygarnijzwierzaka).

Duszka około 5 letnia sunia szukająca domku i przyjaciela (www.morusek. pl).

Franuś (pies), który szedł przez życia sam. Chce mieć przyjaciela (www. psy.pl).

Zastosowanie kategorii PRZYJAŹNI w opisie relacji z psem jest zgodne z konwencją językową, co potwierdza frazeologizm najlepszy przyjaciel człowie$k a$. W badanym materiale zakres stosowania wyrazu przyjaciel jest jednak szerszy — odsyła on do przedstawicieli różnych gatunków. Na uwagę zasługuje także fakt, że hobbyści również o człowieku mówią jako o przyjacielu zwierzęcia. Relacja ta jest wprawdzie - logicznie rzecz biorąc — symetryczna, niemniej jednak w językowym obrazie świata wyraźniej zarysowany jest jej ogląd z jednej tylko, ludzkiej perspektywy. Teksty, które przeanalizowałam, implikują z kolei zwrotny charakter ludzko-zwierzęcej przyjaźni.

Warto także zauważyć innowacyjny sposób wykorzystania kategorii PRZYNALEŻNOŚCI. Nawiązują do niej konwencjonalne sformułowania: mój/jej/jego pies/kot itp., ale także nietypowe wypowiedzi internautów o zwierzętach majacych swojego czlowieka:

4,5mies. (suczka) Dobrusia-mały okruszek czeka na swojego Czlowieka :) (www.morusek.pl).

Maciek to nie narzucający się kompan, był przy osobie starszej, do swojego czlowieka przywiąże się na całe życie (www.koty.pl).

Kot wreszcie miał swojego czlowieka. Czuł się odpowiedzialny za to co oswoił (www.koty.pl).

Cyryl - kot ideał czeka na swojego czlowieka (przygarnijzwierzaka).

Warus (pies) - ogromna przylepa szuka swojego człowieka ;) (przygarnij zwierzaka).

Emotikony, które towarzyszą niektórym użyciom wyrażenia swój człowiek, mogą wskazywać na to, że nadawca zachęca do gry z konwencją językową.

Wspomnijmy też o stosowanej w wypowiedziach dotyczących psów eksperckiej kategorii przewodnika:

Niesamowiecie (sic!) sympatyczny do ludzi. Garnie się do człowieka, potrzebuje przewodnika (www.psy.pl).

Baks - młody, energiczny, skoczny idealny dla kogos kto lubi i chce pracować z psem pies nie dla ciapy bez charakteru - pies dla człowieka który będzie jego przewodnikiem, bedzie z nim pracował, zapewni mu ruch i wyładowanie energii. Pies nakręcony na aport, umie skupic sie i chce się skupic 
na człowieku - przewodniku podatny na naukę - tylko trzeba dać mu szansę. !!!!! (www.psy.pl).

Jest to młodzieniec o niezwykłej wręcz inteligencji. Bardzo szybko uczy się nowych komend i zasad panujących w domu, świetnie pracuje z przewodnikiem, za smaczki zrobi dosłownie wszystko (www.morusek.pl).

Wypowiedzi, w których pada określenie przewodnik, zwykle podejmują wątek szkolenia psa i sugerują jego niezależny charakter, wymagający od człowieka szczególnych kompetencji i zaangażowania.

Częstym określeniem zwierzęcia domowego, prócz imion własnych, jest też w badanym materiale potoczna nazwa gatunku, jej derywat o hipokorystycznym charakterze bądź hiponim odsyłający do płci lub do rasy. Popularne są synonimy pupil i ulubieniec, implikujące serdeczny, uczuciowy charakter relacji. Padają również potoczne określenia czworonóg i czworonożny ${ }^{10}$ (w połączeniu z rzeczownikiem przyjaciel) ${ }^{11}$. Odnalazłam także metaforę bracia mniejsi ${ }^{12}$ (www. braciamniejsi.com.pl).

\section{Określenia przyjęcia zwierząt pod swój dach}

Sposób nazywania sytuacji wejścia w relację ze zwierzęciem zależy głównie od tego, czy miała ona charakter transakcji handlowej — wówczas pojawią się czasowniki kupić bądź sprzedać — czy też nie. Ciekawsze są sposoby mówienia o tych drugich okolicznościach. Odsyłają do nich potoczne struktury: oddaćl trafić $w$ dobre ręce oraz przygarnaćc. U ich podstaw leży analogiczna konceptualizacja - o opiece nad zwierzęciem mówi się w kategoriach działań wykony-

10 Znalazłam też wypowiedź zawierającą innowacyjne derywaty od tych określeń: Okazyjne posiadanie czworonoga, czy „mniej lub więcejnoga” bardzo często w najlepszym razie kończy się jego oddaniem do schroniska bądź adopcji (www.koty.pl). Neologizm mniejnóg odsyła przypuszczalnie do ptaków, ewentualnie do węży, więcejnóg zaś do stawonogów, takich jak np. chętnie hodowane w domowych terrariach pająki czy patyczaki.

11 Oto przykłady: Gdy zostawiamy pupila samego na kilka godzin, ryzykujemy, że znajdzie sobie jakieś zajęcie, które zagrozi jego zdrowiu i naszemu mieszkaniu (www.psy.pl). Kociak potrafi się odwdzięczyć, choć robić tego nie musi. Uważny obserwator dostrzega takie zachowania swojego pupila, choć czasem nie trzeba nawet specjalnie się ku temu wysilać (www.koty.pl; http://ulubiency.wp.pl/). Zdecydowanie preferuje towarzystwo ludzi niż zwierząt. Najlepiej jeśli będzie jedynym pupilem $w$ domu, bo różnie dogaduje się z innymi czworonogami (www.morusek.pl). Przerażającym jest fakt, jak dorośli ludzie decydując się na czworonożnego przyjaciela, szybko zmieniaja zdanie (www.koty.pl).

12 Strona internetowa www.braciamniejsi.com.pl jest oficjalną witryną organizacji pożytku publicznego, której pełna nazwa brzmi Stowarzyszenie Humanitarno-Ekologiczne „Dla Braci Mniejszych”. Konwencjonalne, rejestrowane przez słowniki polszczyzny ogólnej, wyrażenie bracia mniejsi znaczy 'zakon franciszkanów', niemniej jednak bywa ono używane także w odniesieniu do zwierząt (patrz: Korpus PWN), których patronem jest właśnie św. Franciszek z Asyżu. 
wanych rękoma. W przypadku czasownika owym działaniem jest obejmowanie i przytulanie ${ }^{13}$, frazeologizmy z kolei mogą sugerować różne rodzaje opiekuńczej aktywności: głaskanie, karmienie itp. Wszystkie te jednostki leksykalne mają w swojej semantyce dodatni komponent aksjologiczny świadczący o tym, że nasza wspólnota komunikacyjna aprobuje działania, do których odsyłają.

Owe konwencjonalne sformułowania są w badanym materiale dosyć częste. Funkcjonuje nawet popularna strona przygarnij.pl. Niemniej jednak najbardziej rozpowszechnionym określeniem interesującej mnie sytuacji, jakie pada na stronach hobbystycznych, jest rzeczownik adopcja i wyrazy pokrewne mu słowotwórczo.

„Wyślij SMS-a do domu” to inicjatywa, która ma pomóc w adoptowaniu starszych psów, których, niestety, prawie nikt nie chce... SMS, czyli Szukający Miłości Staruszek potrzebuje domu, podobnie jak młody pies, ale większość osób boi się przygarniać takie czworonogi (www.psy.pl).

Kandydat do adopcji psa ma możliwość wycofania się z propozycji zaopiekowania się psem na każdym etapie procesu adopcyjnego. Fundacja również może odmówić adopcji psa na każdym etapie tego procesu (aurea.org.pl).

...adopcja, zdjęcia i opisy zwierząt przygotowanych do adopcji i czekających $\mathrm{z}$ utęsknieniem na nowy dom! (animalsi).

Wiele adoptowanych psów, których przeszłości nie znamy, cechuje nerwowość (www.psy.pl).

Opracowania leksykograficzne, z których skorzystałam, informują o stosowaniu wyrazów adopcja i adoptować w odniesieniu do dzieci. Tymczasem na stronach internetowych, które zachęcają do zaopiekowania się zwierzętami, czytamy o kacikach adopcyjnych, ankietach przedadopcyjnych, umowach adopcyjnych, a także o adopcjach wirtualnych 'finansowym wspieraniu zwierzęcia przebywającego $\mathrm{w}$ instytucjonalnym ośrodku opieki'. W badanym materiale obserwujemy zatem rozszerzenie zakresu znaczeniowego rzeczownika adopcja i czasownika adoptować, co należy uznać za innowacyjne, niemniej jednak samo mówienie o ulubionym zwierzęciu w kategoriach dziecka nie jest bynajmniej nowe w polskiej kulturze ${ }^{14}$. Rodzi się pytanie, dlaczego ów zwyczaj stosowania

13 To verbum bywa także używane w znaczeniu literalnym. Pod hasłem przygarnać słownik podaje: ,jeśli przygarnęliśmy kogoś, to 1) objęliśmy go i przytuliliśmy do siebie serdecznie, aby okazać mu nasze uczucie lub uchronić go przed jakimś niebezpieczeństwem 2) daliśmy mu schronienie w swoim domu i zaopiekowaliśmy się nim" (Bańko (red.) 2000). Definicje słownikowe nie mówią wprawdzie o zwyczaju używania czasownika przygarnąć w odniesieniu do relacji ludzi i zwierząt, niemniej jednak przykłady podawane w opracowaniach leksykograficznych świadczą o typowości takich użyć: przygarnać kota ze schroniska, przygarnać kundla, przygarnać przybtędę (Dubisz (red.) 2005).

14 W literaturze osiemnastowiecznej znajdziemy liczne tego przykłady, które omówił w swoim studium Radosław Grześkowiak (2013). 
wyrazów adopcjaladoptować tak rozpowszechnił się na hobbystycznych stronach internetowych, pomimo obecności w polszczyźnie konwencjonalnej jednostki przygarnąć, niosącej podobne znaczenie i mającej pozytywne konotacje. Przyczyna leży być może w samej strukturze leksemu adopcja, który jest krótszy od nominalizacji przygarnięcie. Bardziej prawdopodobne jest jednak to, że powód ma charakter semantyczno-stylistyczny. Adopcja konotuje 'urzędowość' i 'związek z systemem prawnym', dodaje zatem powagi kwestii wzięcia żywego stworzenia pod opiekę. Ponadto w sensie literalnym adoptować odnosi się do dzieci, które — zgodnie z kulturowym modelem — należy otaczać troską i miłością. W związku z tym użycie tego czasownika lub jego derywatów na oznaczenie relacji człowieka ze zwierzęciem domowym projektuje pożądaną przez nadawcę postawę tego pierwszego.

$\mathrm{W}$ wypowiedziach internautów popularne są również jednostki z obszaru pojęciowego RODZINY:

Pistis - 5-cio miesięczny kociak chce zamieszkać ze swoją rodziną. Franek

— śliczny kocurek stracił domek. Teraz czeka na nową rodzinę (przygarnijzwierzaka).

\section{Rodziny wielopsie (psy.pl).}

Jagoda to około 4-letnia sunia w typie mini bullterriera, która szuka naprawdę odpowiedzialnego domu (morusek.pl).

Warto w tym kontekście wspomnieć o rozpowszechnionych wśród internautów wyrażeniach dom stały i dom tymczasowy 'prywatny dom wolontariusza, w którym zwierzę oczekuje na znalezienie stałego opiekuna'. Odzwierciedlają one model działania instytucji zajmujących się opieką nad bezdomnymi zwierzętami. O ich skonwencjonalizowaniu świadczą użycia form znacznie skróconych, zrozumiałych dla osób wywodzących się z interesującego mnie środowiska:

Pilnie potrzebny tymezas dla szczeniaczka 8 tyg !!! Sunia miała być odebrana przez DS, ale DS chyba rozmyślił się bo zerwał kontakt, nie odbiera telefonów od tygodnia DT nie może dłużej trzymać malucha i rozważa oddanie małej do schronu, a to oznacza tragedię (www.facebook.com/FoondacjaFelis).

Sporadyczne, ale godne uwagi, są także żartobliwe zachęty do zaopiekowania się zwierzakiem, w których relacja z nim przedstawiana jest w kategoriach ROMANSU:

Przyjazny i czarujący mały Masaj szuka domu. Daj się uwieść przystojniakowi :). Kociaki Okruszki już można się zakochiwać! (przygarnijzwierzaka). 


\section{Językowe ujęcia procesu uczenia zwierząt}

W zasobie leksykalnym polszczyzny występuje czasownik tresować oraz wyrazy pokrewne treser i tresura, które odnoszą się do działań, jakie człowiek podejmuje wobec zwierzęcia, w szczególności psa, by wyposażyć je w pożądane przez siebie umiejętności. Słowa te obrosły jednak w negatywne konotacje 'brutalności' i 'przymusu'. Nie dziwi zatem, że na stronach miłośników zwierząt padają one raczej sporadycznie i rzadko spotyka się je w pozytywnych kontekstach. Zastępują je wyrazy i wyrażenia, których zwykło się używać w odniesieniu do kształcenia ludzi, takie jak uczyć, szkolić, wychowywać czy socjalizować, a także problemy wychowawcze czy metoda wychowawcza:

Szkoleniowcy prowadzący kursy posłuszeństwa wciąż słyszą od sfrustrowanych właścicieli psów: - Ja bym tylko chciał, żeby on przychodził na zawołanie... A przecież naprawdę łatwo jest tego nauczyć — zwłaszcza szczeniaka (www.psy.pl).

Szkolenie psa przy użyciu kar fizycznych jest nie tylko przestarzałą metodą, ale przede wszystkim nieefektywną (www.zpazurem.pl).

Wielu właścicieli psów i kotów spotyka się z problemami wychowawczymi u swoich pupili (www.zpazurem.pl).

Siłą psa nie wychowasz [...]. Jeśli przewodnik używał siły fizycznej jako metody wychowawczej, bez narzędzia kontroli, jaką jest smycz i kolczatka, nie będzie potrafił nad psem zapanować. Warto zwrócić na to uwagę wybierając szkołę dla swojego czworonoga (www.zpazurem.pl).

Najprostszym i najprzyjemniejszym aspektem wychowywania psa jest dla właścicieli socjalizowanie szczeniaka. A co zrobić, gdy mamy do czynienia z psem zupełnie nie zsocjalizowanym, a już dorosłym? (www.psy.pl).

Miłośnicy zwierząt domowych wchodzą czasem w polemiczny dialog z konwencją, czego wyrazisty przykład stanowi hasło: Wychowuję, nie tresuję. Jednym ze sposobów podważenia tradycyjnej kategoryzacji jest także gra językowa polegająca na zmianie układu ról w relacji tresury:

Doskonały treser ludzi [...]. Wyuczył nas doskonale, że kiedy kot chce wyjść — to wychodzi, my jesteśmy od tego, aby cały proces umożliwić. [...] Ostatnio usiłował zmusić nas do wyłączenia deszczu - chciał się przejść po podwórku, ale padało. Muszę przyznać, że prawie mu się udało, taki był przekonujący... (zurawiejka-huculy.gogler.pl).

W języku internautów występują także eksperckie określenia osób zawodowo zajmujących się szkoleniem zwierząt, zwłaszcza psów, takie jak: szkoleniowiec, trener, instruktor, behawiorysta, zoopsycholog, terapeuta, terapeutka za- 
chowań zwierząt towarzyszacych, instruktor szkolenia psów; także treser bywa traktowany jako subkategoria profesjonalna. Wymienione tu jednostki nie są ścisłymi synonimiami, niemniej jednak relacje sematyczne między nimi nie rysują się w badanym materiale wyraźnie.

\section{Sposoby mówienia o śmierci zwierzęcia}

Kolejnym aspektem relacji homo-animal, który w wypowiedziach internautów zyskał niekonwencjonalne wykładniki językowe, jest umieranie zwierzęcia i związane z nim ludzkie odczucia. Jak wiadomo, w tradycji kulturowej zwierzęca śmierć znacząco różni się od śmierci człowieka. Znalazło to odzwierciedlenie w języku: człowiek umiera, zwierzę zaś zdycha ${ }^{15}$ bądź pada (Pajdzińska 1990; Wysoczański 2012). Ludzka śmierć bywa ponadto tabuizowana, toteż w odniesieniu do niej stosowane są liczne konwencjonalne eufemizmy, nierzadko metaforyczne (Dąbrowska 1998. Niektóre z nich przedstawiają to zjawisko w bardzo ogólnych kategoriach przemieszczania się w przestrzeni (odejść, opuścić kogoś czy kogoś nie ma już wśród nas). Inne odwołują się do chrześcijańskich wyobrażeń transcendencji: wizji nieba, raju, spotkania z Bogiem czy Sądu Ostatecznego. Śmierci zwierząt natomiast żadne tabu nie obejmuje, toteż eufemizacja zasadniczo jej nie dotyczy. Dodajmy, że — zgodnie z konwencją — użycie sformułowań odwołujących się do sacrum jest zarezerwowane dla mówienia o ludziach; także słowa odsyłające do tego, co jest związane z oddawaniem rytualnej czci zmarłym — pogrzeb, cmentarz, nagrobek, żałoba i inne - tradycyjnie odsyłają do ludzkiej sfery. Ich odniesienie do zwierząt jest nacechowane, co poświadcza np. kolokwialne wyrażenie żałoba po kocie 'brud za paznokciami' (uzus).

$\mathrm{Na}$ hobbystycznych witrynach internetowych zauważamy językowe przejawy odejścia od tradycyjnego rozgraniczania śmierci zwierzęcej i ludzkiej, niemające jednak radykalnego charakteru. Ich użytkownicy zwykle wypowiadają się na ten temat na specjalnych podstronach. Wielu z nich wyraża tam swój żal po stracie ulubieńca i uzyskuje wsparcie innych miłośników żywych stworzeń. Kategoria żałoby, przywoływana tym kontekście, jest traktowana serio.

Jeśli ktoś w naszym otoczeniu cierpi z powodu utraty pupila, bądźmy dla niego wyrozumiali, nie mówmy „to tylko kot”, ,weź innego”, bądźmy obok, wysłuchajmy n-ty raz historii kota, podsuńmy chusteczkę, gdy trzeba, albo włas-

15 Zdecht pies! to z kolei żartobliwa konwencjonalna fraza, służąca jako komenda zachęcająca zwierzę do udawania martwego: ...nie ujada w nocy. zna komendy: na swoje, zdecht pies, siad, leżé, daj glos, noga, tapa, poproś. uwielbia pływac, aportuje wszystko co da sie zlapac w morde, nie skacze na ludzi, lubi dzieci, mozna mu grzebac w misce kiedy je... (www.morusek.pl). Bardzo szybko się uczy: zna komendy: siad, daj tapę, przybij piątke, leżeć $i$ zdecht pies (www.morusek.pl). 
nego kota do wygłaskania. Nieoceniające wsparcie i przyzwolenie na przeżywanie żałoby, rzadkie w obecnym świecie, to prawdziwy skarb (koty.pl).

Internauci wspominają wspólną z ulubieńcem przeszłość i kreślą wizje tego, co się z nim aktualnie dzieje ${ }^{16}$. Środki wyrazu używane w wypowiedziach na te tematy są dość zróżnicowane. W niektórych tekstach pojawia się konwencjonalny czasownik zdechnać:

Witam, mój kotek na coś zachorował i zdechl ; miał niecałe 2 miesiące (www.koty.pl).

...nie może to być duży pies gdyż ma on trafić do dziadków którzy z chęcią zaopiekują sie małym stworzeniem. Nie dawno zdechła im suczka kunelka (www.morusek.pl).

BARDZO, bardzo współczuję. Mój ukochany kocurek 5 miesięczny ALVIN zdechł 28.10.10 Ja też nie potrafię się z Alvinkiem pożegnać. Ciągle w głowie tylko wspomnienia... (www.psy.pl).

Użytkownicy hobbystycznych stron internetowych częściej jednak wybierają inne określenia śmierci zwierząt: czasownik umrzeć oraz eufemizmy, takie jak: odejść, ktoś opuścit kogoś, przegrać (walkę) z choroba, dla kogoś pomoc przyszła za późno, poddać się, kogoś nie ma już z nami, ktoś jest nieobecny. Być może dzieje się tak ze względu na negatywne skojarzenia, którymi czasownik zdechnać obrósł w języku ogólnym. Niewykluczona jest także intencja zacierania wytyczonej przez kulturę i język granicy między śmiercią człowieka i zwierzęcia.

Gdy kot pojawia się w naszym domu, nie myślimy co będzie, gdy umrze. Koty żyją do 20 lat, to sporo jak na zwierzęta towarzyszące. Niestety prędzej czy później każdy żywy organizm odchodzi (koty.pl).

Współczuję utraty pieska;(... To smutne, że nasi psi przyjaciele tak szybko odchodzą... (www.psy.pl).

Niestety Słodziaka nie ma już z nami, tak bardzo boli gdy odchodzi malutki kochany kociak... (fdz-animalia.pl).

Odeszły od nas zanim zdążyły nacieszyć się życiem, przegrały nierówna walkę z ciężka chorobą :( (fdz-animalia.pl).

Maleńki kotuś kolejna przegrana walka z panleukopenią :( (fdz-animalia. $\mathrm{pl})$.

Pomimo naszych starań kicia po dwóch dniach poddała się :( Jej braciszek odszedl samotnie na dworze... (fdz-animalia.pl).

16 Trudno dociec, czy rzeczywiście w nie wierzą; rozstrzyganie tej sprawy nie jest zresztą zadaniem lingwisty. Tak czy inaczej, już samo wykreowanie pozytywnej narracji o pośmiertnym losie zwierzęcia pełni fukcję katartyczną i służy odzyskaniu pogody ducha. 
Dla tego malca niestety pomoc przyszła za późno... (fdz-animalia.pl).

Odeszla po ciężkiej chorobie — w Walentynki 2013r. Pozostawila żal i rozpacz w sercach właścicieli (fdz-animalia.pl).

A tak wyglądał nasz pierwszy PON — Maks urodził się chyba w maju 1994 roku a opuścil nas 19 stycznia 2000 roku (ponforum.x25.pl).

Galeria Kotów Nieobecnych (www.koty.pl).

Psy, które odeszły, wydarzenia, które wzruszały, chwile, które cieszyły — galeria psów nieobecnych (www.psy.pl).

Wiersze O Psach Które Odeszły (psy-pies.com).

Godne uwagi są także sposoby mówienia o tym, co ze zwierzętami dzieje się po śmierci. Chrześcijańska wizja nieba czy też raju w zasadzie nie jest wykorzystywana. Kiedy do internetowej wyszukiwarki wpiszemy psi/koci raj, odnajdą się przede wszystkim rozmaite oferty usług dla psów i kotów. Współczesnym hobbystom nie trafiła też chyba do przekonania znana literacka wizja Jana Brzechwy ze szkolnej lektury pt. Pan Kleks. Znalazłam natomiast odwołania do wiersza Barbary Borzymowskiej pt.: Moje psie niebo, który bywa chętnie cytowany:

Dokąd idą psy, gdy odchodzą? / No bo jeśli nie idą do nieba, / to przepraszam Cię, Panie Boże, / mnie tam także iść nie potrzeba. // Ja poproszę na inny przystanek / tam gdzie merda stado ogonów. / Zrezygnuję z anielskich chórów / tudzież innych nagród nieboskłonu. // W moim niebie będą miękkie sierści, / nosy, łapy, ogony i kły / W moim niebie będę znowu głaskać / moje wszystkie pożegnane psy (psy-pies.com/tagi_serwisu/tag/wiersze-o-psach-ktore-odeszly.html).

Zwróćmy uwagę na zawartą w tekście sugestię, iż zwierzęta do nieba nie idą. $\mathrm{Z}$ tego też względu ich miłośniczka prosi na inny przystanek i projektuje własną krainę wiecznego szczęścia, różną od raju, którego wizerunek został utrwalony w kulturze. Na stronach hobbystycznych pojawia się także wyrażenie kocie niebo ${ }^{17}$.

Internautom najbardziej jednak spodobał się literacki obraz tęczowego mostu — rainbow bridge — z prozy poetyckiej, napisanej oryginalnie w języku angielskim (www.rainbowsbridge.com). Ta metafora (zapisywana wielkimi bądź małymi literami) zyskała wśród hobbystów niezwykłą popularność. Przywołajmy kilka przykładów jej użycia:

...chcą pożegnać się ze swym przyjacielem, aby móc przeprowadzić swojego przyjaciela przez Tęczowy most (psy-pies.com).

${ }^{17}$ My wierzymy w Kocie Niebo. Bo tak jest łatwiej. W końcu koty to magiczne stworzenia, maja zdolność widzenia i styszenia tego, czego my nie jesteśmy w stanie. Dlaczego więc nie mogtyby wędrować między wymiarami? (www.koty.pl). 
Musialam uspic mojego kotka niedawno temu i strasznie mi sie z tym pogodzic, byl nieuleczalnie chory i cierpial. Mam nadzieje ze biega tam gdzies za teczowym mostem czekajac na ten dzien kiedy znowu bedziemy razem :-((((( (koty.pl).

Tęczowy Most to miejsce niezwykłe. To właśnie tam, za tym mostem spotykają się nasi podopieczni, gdy nadchodzi ich czas. [...] Za Tęczowym Mostem - zatrzymuje się czas, a nasze zwierzęta, wolne od strachu, bólu, głodu i bezdomności - czekają na nas (fdz-animalia.pl).

Atos odszedł w kochającym go domu za Tęczowy Most. Rodzina rozpacza, my tez, bo Atos był jedyny w swoim rodzaju — wierny, opiekuńczy, całkowicie pozbawiony agresji. Był idealny (fdz-animalia.pl).

Tylko Brittcie udało się przeżyć... Czasem, gdy tak stoi przy furtce swojego boksu z noskiem wciśniętym między kraty mamy wrażenie, że żałuje, że nie odeszla za tęczowy most razem z rodzeństwem... (www.morusek.pl).

Nasze malutkie kochane Słoneczko, niestety nie dane Ci było dorosnać... Odszedł zbyt szybko, po długich cierpieniach z powodu PSS. Biegaj nasz malutki, u boku Tigry, za Tęczowym Mostem... (www.republika-marzen.pl).

Wszyscy mówią, że jestem bezproblemowy, przyjazny i spokojny. Poradzę sobie na długich spacerkach — nie musisz się przejmować. Czy proszę o tak wiele? Proszę o przyjaciela — dam Ci całe serce ... póki tęczowy most nas nie rozdzieli... (www.morusek.pl).

Rodzi się pytanie, dlaczego ta przenośnia tak silnie oddziałała na wyobraźnię miłośników zwierząt. Pewną rolę odegrała tu przypuszczalnie moda na zapożyczenia $\mathrm{z}$ angielskiego obszaru kulturowego, lecz nie ona wydaje się w tym wypadku czynnikiem najważniejszym, ale to, że metafora tęczowego mostu w kilku aspektach koresponduje z obrazem świata utrwalonym w polszczyźnie, a jednocześnie nie narusza tabu językowego. Członkowie naszej wspólnoty kulturowej ujmują śmierć w kategoriach ruchu w przestrzeni, przechodzenia $\mathrm{z}$ jednego obszaru do innego, a most - w sensie fizycznym - służy właśnie do takiego przemieszczania się, dlatego może łatwo posłużyć za konkretyzację drogi w zaświaty. Z kolei tęcza, przypominająca go kształtem, kojarzy się bardzo pozytywnie. Słowniki współczesnej polszczyzny ogólnej podają: „Jako tęczowe określamy to, co wydaje się nam bardzo atrakcyjne i nastraja nas optymistycznie" (Bańko (red.) 2000), co potwierdzają związki wyrazowe: tęczowe perspektywy, tęczowa przyszłość, coś maluje się w tęczowych barwach 'zapowiada się pomyślnie', a także patrzeć (w kogoś) jak w tęczę 'z zachwytem, uwielbieniem' (Dereń, Polański 2012). Konotacje tęczy czynią zatem ten leksem szczególnie przydatnym w kreowaniu tekstowych obrazów szczęśliwego życia. Metafora ta pozwala w pozytywny, krzepiący sposób mówić o śmierci, bez przywoływania wątków sakralnych, 
dzięki czemu nie narusza konwencji kulturowej i nie zaciera granicy między tym, co ludzkie, a tym, co zwierzęce.

Warto na koniec wspomnieć, że w wypowiedziach na temat śmierci zwierząt zdarzają się odwołania do rytuału kojarzonego z kultem ludzkich zmarłych:

Tutaj możemy pożegnać naszych kudłatych Przyjaciół, założyć wątki PON-om, które odeszły, zostawić kwiatek w rocznicę, zapalić świeczkę... Podzielić się wspomnieniami (ponforum.x25.pl).

Zapraszamy do składania kondolencji dla osób, których koty odeszły (www. koty.pl).

...ja zapalę świeczkę za Froda, labka który żył 3 lata... (www.fundacjaprima pl).

Takie sformułowania czasem budzą sprzeciw, czego dowodzi polemika, jaka toczyła się na temat ich stosowności na stronie www.fundacjaprima.pl.

\section{Podsumowanie}

Badania zwyczajów komunikacyjnych miłośników zwierząt, przeprowadzone na materiale wypowiedzi zamieszczonych na hobbystycznych stronach internetowych, pozwoliły zaobserwować leksykalne przejawy aktywnego, refleksyjnego i krytycznego stosunku reprezentantów tego środowiska do językowej konwencji. Za próby dialogu z tradycją można uznać stosowanie niestandardowych określeń podmiotów relacji człowiek-zwierzę, sytuacji wejścia w ową relację, a także sposoby mówienia o uczeniu zwierzęcia, jak również o jego śmierci, różne od tych, których stosowanie poświadczają opracowania leksykograficzne. Jednakże, co znamienne, w tekstach dotyczących zwierzęcego umierania doszła do głosu ta sama potrzeba, która wywarła przemożny wpływ na obraz istot żywych w polszczyźnie ogólnej, a mianowicie imperatyw rozróżnienia tego, co uznawane za swoiście ludzkie, od tego, co wspólne całej przyrodzie.

\section{Bibliografia}

Anusiewicz J. (1994), Lingwistyka kulturowa. Zarys problematyki, Wrocław.

Dąbrowska A. (2003), Wężem pożądań wejdę do twej duszy - nazwy zwierząt w polskim słownictwie erotycznym, [w:] Opozycja homo-animal w języku i kulturze („Język a Kultura” 15), Wrocław, s. 157-188.

Dąbrowska A. (red.) (2003), Opozycja homo-animal w języku i kulturze, „Język a Kultura” 15, Wrocław.

Grybosiowa A. (2003), Jak historyk języka polskiego rozumie opozycję homo-animal, [w:] Opozycja homo-animal w języku i kulturze (,Język a Kultura” 15), Wrocław, s. 9-15. 
Grześkowiak R. (2013), Zazdrość i pomówienia. Pieski w panieńskiej pościeli, [w:] idem, Amor curiosus. Studia o osobliwych tematach dawnej poezji erotycznej, Warszawa, s. 69-141, https:// www.academia.edu/8157261.

Kamińska-Szmaj I. (2003), Człowiek zwierzęciem politycznym, [w:] Opozycja homo-animal w języku i kulturze („Język a Kultura” 15), Wrocław, s. 137-141.

Kempf Z. (1985), Wyrazy „,gorsze” dotyczace zwierząt, „Język Polski”, z. 2-3, s. 125-144.

Kępa-Figura D. (2007), Kategoryzacja w komunikacji językowej na przykładzie leksemu „ptak”, Lublin.

Krawczyk-Tyrpa A. (2003), Niedźwiedzie i ludzie - opozycja rozmyta, [w:] Opozycja homo-animal w języku i kulturze (,Język a Kultura” 15), Wrocław, s. 244-250.

Libura A. (2001), Wielki łańcuch bytów jako element językowego obrazu świata i zasada współorganizująca semantykę tekstów artystycznych, [w:] Semantyka tekstu artystycznego, red. A. Pajdzińska, R. Tokarski, Lublin, s. 191-206.

Mosiołek-Kłosińska K. (1998), Stereotypy konia przekazywane przez język polski i francuski, [w:] Stereotyp jako przedmiot lingwistyki. Teoria, metodologia, analizy empiryczne, red. J. Anusiewicz, J. Skawiński, Wrocław.

Nowakowska A. (2003), Człowiek jak zwierzę. Sfrazeologizowane porównania doczasownikowe na podstawie Stownika frazeologicznego języka polskiego, [w:] Opozycja homo-animal w języku i kulturze (,Język a Kultura” 15), Wrocław, s. 97-102.

Pajdzińska A. (1990), Antropocentryzm frazeologii potocznej, „Etnolingwistyka” 3, s. 59-68.

Peisert M. (2003), Sus domesticus — zwierzę, którego nazwy używać nie wypada, [w:] Opozycja homo-animal w języku i kulturze (,Język a Kultura” 15), Wrocław, s. 149-155.

Skawiński J. (2001), Językowy aspekt badań nad zwierzętami w kulturze, „Zeszyty Etnologii Wrocławskiej", nr 1.

Termińska K. (2003), Przekraczanie opozycji zwierzę-czlowiek w cywilizacjach Morza Śródziemnego, [w:] Opozycja homo-animal w języku i kulturze (,Język a Kultura” 15), Wrocław, s. 17-25.

Tokarski R. (2001), Słownictwo jako interpretacja świata, [w:] Wspótczesny język polski, red. J. Bartmiński, Lublin.

Tokarski R. (2002), Konceptualizacja zwierząt w potocznej świadomości językowej, [w:] Prawna ochrona zwierzat, red. M. Mozgawa, Lublin, s. 11-18.

Tokarski R. (2013), Światy za słowami. Wykłady z semantyki leksykalnej, Lublin.

Wierzbicka A. (2006), Semantyka i etnobiologia, [w:] eadem, Semantyka. Jednostki elementarne $i$ uniwersalne, Lublin, s. 389-415.

Wolny M. (2003), Językowy obraz starości ludzi i zwierząt w polszczyźnie, [w:] Opozycja homo-animal w języku i kulturze (,Język a Kultura” 15), Wrocław, s. 189-199.

Wysocka A. (2003), Zwierzęciem bywam bardzo rzadko. O roli konotacji stowa „zwierzę” i jego hiponimów w erotykach Marii Pawlikowskiej-Jasnorzewskiej, Anny Świrszczyńskiej i Haliny Poświatowskiej, [w:] Język polski. Współczesność. Historia, red. W. Książek-Bryłowa, H. Duda, Lublin, s. 175-187.

Wysocka A. (2011), Zwierzęta w poezji Marii Pawlikowskiej-Jasnorzewskiej a językowy obraz świata - rekonesans, [w:] Język pisarzy. Problemy stownictwa („Prace Językoznawcze Instytutu Filologii Polskiej UKSW" 3), Warszawa, s. 105-118.

Wysoczański W. (2003), Opozycja homo-animal z perspektywy regut postępowania (na materiale frazemów wybranych języków), [w:] Opozycja homo-animal w języku i kulturze („Język a Kultura" 15), Wrocław, s. 81-95.

Wysoczański W. (2012), Umieranie i śmierć. Wielowymiarowość językowa, Wrocław.

Zaron Z. (1998), Czy zwierzę to ktoś? Językowe dowody podmiotowości zwierząt, „Prace Filologiczne" XLIII, s. 507-513.

Zimnowoda J. (2003), Opozycja homo-animal w ekspresywnych zwrotach językowych, [w:] Opozycja homo-animal w języku i kulturze (,Język a Kultura” 15), Wrocław, s. 103-115. 


\section{Słowniki}

Bańko M. (red.) (2000), Inny słownik języka polskiego, Warszawa.

Bąba S., Liberek J. (red.) (2002), Stownik frazeologiczny współczesnej polszczyzny, Warszawa.

Dąbrowska A. (1998), Stownik eufemizmów polskich, czyli w rzeczy mocno, w sposobie łagodnie, Warszawa.

Dereń E., Polański E. (2012), Wielki słownik języka polskiego, Kraków.

Dubisz S. (red.) (2005), Uniwersalny stownik języka polskiego, Warszawa.

Kłosińska A., Sobol E., Stankiewicz A. (red.) (2005), Wielki słownik frazeologiczny z przysłowiami, Warszawa.

Wiśniakowska L. (red.) (2006), Stownik wyrazów bliskoznacznych PWN, Warszawa.

\section{Cytowane źródła internetowe (dostęp: marzec-maj 2014)}

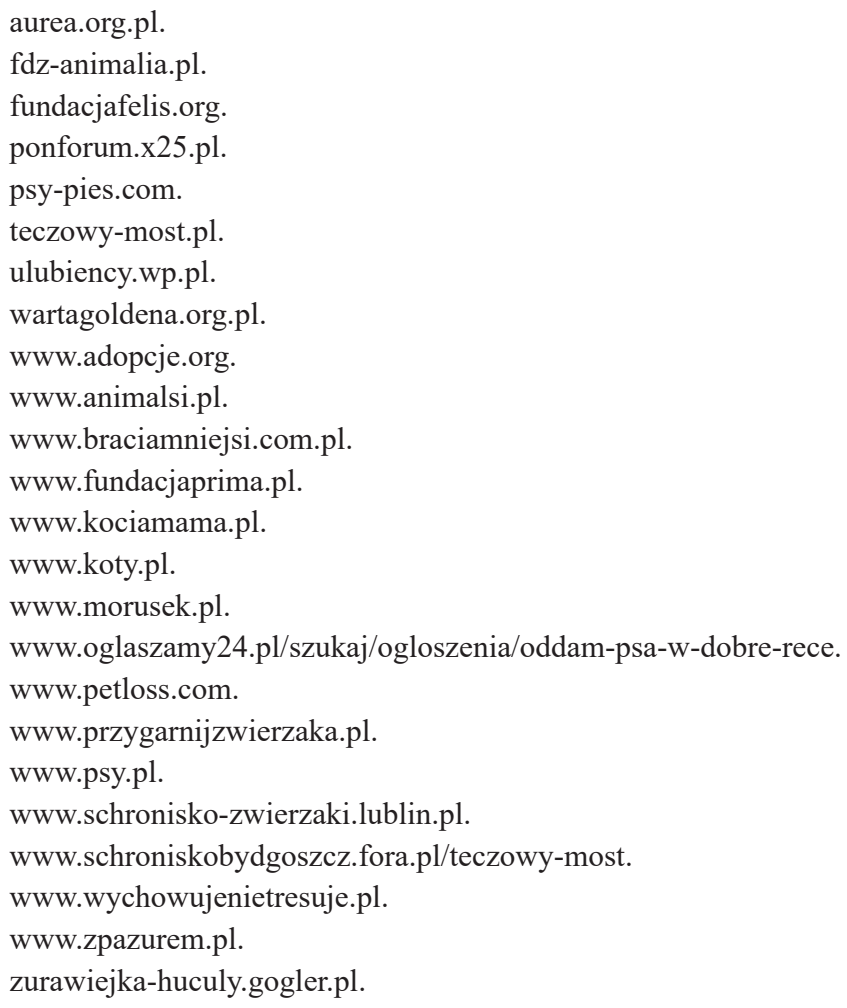




\section{A few innovative ways of speaking about homo-animal relationships by contemporary animal lovers}

\section{Summary}

The study concerns the communication habits of animal lovers, considered against the background of the linguistic picture of the world, which is generally anthropocentric. The research material are comments posted on hobby websites. The analyses allowed the author to observe the active, reflective and critical attitude of many representatives of the community towards linguistic conventions. Its members attempt a dialogue with the tradition by using innovative expressions of people in relation to animals and animals in relation to people, new ways on naming the process of teaching the animal, as well as its death. However, the texts that speak of the latter case revealed the same need, which had a profound impact on the image of living beings in general Polish language - the imperative to distinguish between what is considered to be specifically human and that which is common throughout nature.

Keywords: linguistic picture of animals, human-animal relationship, innovations in the language of Internet users, language of pet lovers 